\title{
FORECASTING OF THE TOURISM INDUSTRY DEVELOPMENT AND THE COVID-19 PANDEMIC CONSEQUENCES: GEOGRAPHICAL AND INTERNATIONAL ORIENTATION
}

\author{
Olesia lastremska', Oleksandra Kononova²
}

\begin{abstract}
Restrictions on transportation between countries because of lockdown caused by the prevalence of morbidity COVID-19 have slowed down economic activity worldwide. Therefore, in this paper, we examine and estimate the short-term economic impact of the COVID-19 pandemic on the global market situation in terms of the international tourism industry. The purpose of the study is to analyze the current economic situation of the world tourism sector, which suffered the most because of the COVID-19 pandemic, determine the main tourist flows (inbound and outbound tourism), and identify main tourism trends that characterize travel and tourism in 2020, to form practical directions for improving the tourism industry, domestic tourism in particular. This article analyzes the dynamics of international touristic destinations for the period 2019-2020, with regard to the pre-pandemic period and during the COVID-19 lockdown. Also, the dynamics of destinations of international tourists by different regions and the world in general for different types of travel limitations in 2020 are analyzed. It is detected an enhancement in percentage change of tourism destinations from July 2020 because the world began to open up to international tourism, mainly in the European Union. In this article, it is considered that the implementation of travel restrictions is clearly affected international travel. The dynamic of the international tourists' destinations with a complete/partial closure of borders and other restrictions by region in 2020 during the COVID-19 pandemic are analyzed. The major trends in the tourism sector during the coronavirus crisis are highlighted. The main practical directions for the resuscitation of the tourism industry have been formed, which will have to reduce the negative consequences of the COVID-19 pandemic and created a basis for increasing the competitiveness of domestic tourism. It is determined that support for the development of the tourism industry at the central and local levels should be based on the expected preferences of tourists and the risk of using illegal resorts with the possibility of infection. The article examines the main problems of the tourism sphere of Ukraine, which arise as a result of the introduction of measures to overcome the coronavirus pandemic in the world and in Ukraine in particular. Using the experience of other countries and international recommendations, measures for intersectoral cooperation in the context of increased epidemic risks are proposed. The article reveals the peculiarities of the development of the tourist sphere of Ukraine in the conditions of increased epidemic risks. Modern tendencies of functioning of the tourist sphere of the country are investigated. The tourism sector is suffering on a global scale due to the implementation of measures to overcome the coronavirus pandemic and the uncertainty of further development of the situation. According to various scenarios, in 2020 the volume of international tourist arrivals is expected to fall by $58-78 \%$ compared to last year. According to experts, the recovery of demand to the level of 2019 will take at least two years. According to experts, the sphere of tourist services of the coronavirus crisis period will be characterized by giving consumers priority in terms of choice of shorter rest periods, a predominance of individual movement and individual accommodation, choice of health, sea, and rural tourism.
\end{abstract}

Key words: tourist flows, international tourism, quarantine restrictions, epidemic risks, COVID-19, international prognosis, tourism development.

JEL Classification: C82, E32, L90, 119, Z32

\footnotetext{
Corresponding author:

${ }^{1}$ Simon Kuznets Kharkiv National University of Economics, Ukraine.

E-mail: Iastremska.o@gmail.com

ORCID: https://orcid.org/0000-0003-1865-0282

ResearcherID: 0000-0003-1865-0282

${ }^{2}$ Prydniprovska State Academy of Civil Engineering and Architecture, Ukraine.

E-mail: oleksandrakononova@gmail.com

ORCID: https://orcid.org/0000-0002-7215-8574

ResearcherID: AAG-2757-2019
} 


\section{Introduction}

Today, tourism continues to be the key industry of the national economy in terms of economic growth, as it contributes to the national income increasing and the payment balance improving, as well as intensifies the multiplier effect - helps to increase the country's competitiveness. Recognition of the growing role of tourism in creating new jobs, reducing poverty, developing small businesses, and increasing economic growth is reflected in the formation of tourism development strategies both in developed and developing countries.

The global coronavirus pandemic has affected all spheres of human life negatively. Tourism is one of the sectors of the world economy that has suffered the most from the movement restrictions. As a result, the study of theoretical and practical issues of stabilizing the tourism industry functioning, preventing the negative impact of quarantine restrictions, and further ensuring the sustainability of the industry is not just relevant but a priority in today's dynamic changes in the economic environment.

The aim of the paper is to research the issue of the tourism industry stabilization in the context of quarantine restrictions using the other countries' experience and international recommendations, as well as to justify measures to accelerate the recovery of this area in the conditions of high epidemic risks.

\section{Methodology of research}

\subsection{The tourist sphere development in the conditions of increasing epidemic risks}

The COVID-19 pandemic is the hardest experience the world has faced since World War II. The crisis will have serious consequences on the global economy, and according to the IMF report, the projected decline in GDP in Ukraine from April 2020 will reach 7.7\% (Tourism and transport in 2020 and beyond, 2021).

A number of international organizations, including the IMF, the World Bank, and the OECD, have published their economic forecasts of the effects of the COVID-19 crisis on the world economy. According to this report in 2020, the GDP of Ukraine is projected to fall to $7.7 \%$ with unemployment reaching $10 \%$. Inflation is expected to be declined in 2020 in Ukraine and worldwide. According to the report, all countries, including Ukraine, will be able to restore their economic situation by 2022 but it is impossible to fully compensate for the negative consequences of the pandemic in $2020-2021$. It is projected that the international economy will be able to reach the economic indicators of 2020 only in 2023 (Communication from the commission COVID-19, 2021).

There are quite different estimates for the further recovery of the global economy - from the V-shaped scenario, which provides the economic recovery in 2021, to a longer recovery and even a long-term recession.

In 2019, the number of international tourists reached 1.5 billion people, which is 4 percent more than in 2018 . Tourism was stopped in mid-March 2020. In the first months of the year, the number of international tourists decreased by $56 \%$ and in May - by $98 \%$. This resulted in a loss of almost 320 billion USD in the form of export, which is more than three times the losses of the global economic crisis in 2009 (Communication from the commission COVID-19, 2021).

Prospective scenarios indicate the possible reduction of tourists' number and revenues from international tourism by $58-78 \%$ throughout the year that depends on the pandemic spread, the duration of travel restrictions, and the process of gradual border opening, which has been already begun. Such a serious problem may reduce the number of international tourists by 850 million -1.1 billion people and lead to a loss of 910 billion - 1.2 trillion USD in the form of export earnings from tourism, which will jeopardize the tourism sector from 100 to 120 million jobs. There are still many challenges ahead, including the unknown pandemic dynamics and how consumer confidence will be restored. According to the forecasts of the International Monetary Fund, the volume of the world economy in 2020 will decline sharply - by $4.9 \%$, although it is expected that in 2021 the forecast will be improved (World Tourism Organization (UNWTO) reports (2020). Although countries and international organizations have taken a number of measures to mitigate the socio-economic consequences of COVID-19 and stimulate tourism recovery, the scale of the crisis requires additional efforts and continued support.

The pandemic impact on the employment in tourism sector is significant. Governments responded immediately to the need to minimize the economic consequences of the COVID-19 pandemic, based on two general approaches: the first is to provide affordable credit lines for business, and the second is to delay debt and tax liabilities. For example, Seychelles and Ecuador have postponed special taxes in the tourism sector, and Kenya, South Africa, China, Lithuania, Portugal, Poland, and Spain have provided needful to pandemic-affected businesses in the form of special funds, a guarantee fund model to pay the travel costs, subsidies, or co-financing of deferred or canceled costs. In Switzerland, hotel lending institutions have provided to existing customers the one-year deferral of depreciation, as well as financed the investments of customers who have financed them with cash flow over the past two years. Georgian banks have announced the debt restructuring for all individuals, especially for travel companies (World Tourism Organization (UNWTO) reports (2020). 
Today in Ukraine, there is a significant lag in the pace of implementation of measures to support the tourism industry that jeopardizes the competitiveness of the industry in the global market during the projected recovery period in 2021 .

\subsection{Features of forecasts forming of tourism industry development}

There are more than 800 million trips in the world every year, half of which is within Europe. About $60 \%$ of these trips are related to recreation. The share of tourism in the world export of goods and services is about $13 \%$, in EU countries - 14\%. The tourism industry accounts for $8 \%$ of the total GDP of the EU countries, provides almost $11 \%$ of economic growth, it employs $12 \%$ of the world's labor force. The main trends of the tourism development in the world are: the duration reducing and increasing of the number of tourist trips, which, in particular, has formed a demand for tourism offers that provide the opportunity to visit a significant number of places in a shorter time; active involvement of states in the competition for influence on the parameters of the international tourist flow, also through the state programs implementation; introduction of the regulatory framework and fiscal policy conducive to the tourism industry development; creation of effective mechanisms for establishing and maintaining the balance between the preservation of natural, historical and cultural resources and tourism activities. According to the World Tourism Organization (WTO), the tourism boom is expected in the 21 st century: the number of travelers in the world by 2020 was up to 1.6 billion people per year, which means the tourist flows increase in 2.4 times compared to 2000 .

The leader in the tourist influx was China (137.1 million). The second most popular destination was the United States (102.4 million), followed by France (93.3 million), Spain (71.0 million), and Hong Kong (59.3 million). The daily expenses of tourists, excluding air transportation costs, have increased to
5 billion USD a day. The largest suppliers of tourist flows are the United Kingdom, Germany, Japan, the USA, and China (World Travel \& Tourism Council, 2020).

In 2001 Ukraine ranked 22nd in the world in terms of the number of foreign tourists (5.8 million people that is about $1 \%$ of the world's tourist flows). According to the WTO's projections of the inbound tourism development in Ukraine, its number should increase to 15.0 million people by 2020 .

The tourism industry development in any country is determined by such factors as (Communication from the commission COVID-19): political and social stability in the country; national policy and interethnic relations; conjuncture of the international tourist market; degree of the tourism state support; the state of the material base of tourism; investment attractiveness of the tourism sector; reasonable pricing policy; integration of domestic tourism into the world tourism; demographic and social structure of the population; safety of tourist trips; availability of highly qualified personnel; national traditions; the existence of recreational areas; natural and human-caused cataclysms that are difficult to predict.

The tourism industry nature causes the low level of reliability of various events forecasts because all of them depend on many factors, some of which are unmanageable. The total risk probability multiplicatively depends on the probabilities of each of the factors. Therefore the forecasting of the tourism industry development requires economic and mathematical methods and models application.

The type of forecast is chosen by time (operational, short-term) and/or territorial level: state, regional, local, etc. The factors that affect the tourism development directly or indirectly are identified and the strength of each factor's influence on the forecast parameters is determined taking into account the risk and uncertainty of the processes. It is known that in the economic risk theory uncertainty is understood as incompleteness or lack of information about the forecast conditions and about costs and results that are most important (Mazaraki, 2019).

Table 1

Forecast of the most popular tourist destinations until 2020

\begin{tabular}{|l|c|c|c|}
\hline \multicolumn{1}{|c|}{ Country } & Tourist influx (million people) & Share in the world tourist market (\%) & Growth dynamics of 2000-2020, \% \\
\hline China & 137.1 & 8.6 & 8.0 \\
\hline USA & 102.4 & 6.4 & 3.5 \\
\hline France & 93.3 & 5.8 & 1.8 \\
\hline Spain & 71.0 & 4.4 & 2.4 \\
\hline Hong Kong & 59.3 & 3.7 & 7.3 \\
\hline Italy & 52.9 & 3.3 & 3.2 \\
\hline UK & 52.8 & 3.3 & 3.0 \\
\hline Mexico & 48.9 & 3.1 & 4.0 \\
\hline Czech Republic & 44.0 & 2.7 & \\
\hline
\end{tabular}

Source: (formed based on Global Europe 2050) 
The appropriate indicators are chosen in the forecasting process, in particular: intensity, mobility, number of tourist flows by types of transport, directions (entry, exit), countries and regions; volumes of service by types of tourism; profit volumes; level of profitability; the number of employees in the industry; material base, etc.

It is necessary to determine the trends and growth rates of these indicators in time and in the spatial dimension.

It is important to establish the reliability level of forecasts and obtain the socio-economic assessment of their implementation, i.e., the calculation of economic, budgetary, commercial, social efficiency.

The long-term forecast of the tourism industry is associated with probabilistic business planning of its development indicators and the assessment of its effectiveness in conditions of uncertainty and risk. These conditions determine the specifics of the forecast. It consists of considering the sources of uncertainties and methods of their consideration in assessing the effectiveness of the forecast. It is also determined the methods of estimating uncertainty by checking the stability of the forecast (especially to external factors changes), formalizing the description of uncertainties, adjusting the forecast parameters. The concept of limit (permissible) values of selected parameters (indicators) is introduced (Mazaraki, 2019).

Alarge number of risks and uncertainties are "inherent" in the implementation of investment projects in tourism, which are crucial in the forecasting of its development. Among the existing mathematical models of forecasting tourism development, it is actually to use those that take into account the crisis phenomena existence. These include models developed by Professor Y. Blokhin (Communication from the commission COVID-19). His concept of socio-economic development of tourism in the large city or region is based on the principle of comparing the costs and revenues. Analytically, it is expressed as follows:

$$
\Sigma S=\{(D 1+(1-k) * D 2)-R\},
$$

where: $\Sigma S$ is a total profit from tourism activities in the city or region;

D1 is an income from inbound tourism;

D2 is an income from outbound tourism;

$R$ is the cost of the tourism development of the city or region;

$k$ is a transmission ratio.

However, this model does not take into account the economic, social, demographic, environmental, and other factors. The tourism development in the world is also influenced by scientific and technological progress, demographic changes, the quality of life improving, increasing the duration of free time, vacations, economic and political stability, and a number of other factors.

\section{Results and discussion}

\subsection{Economic consequences of the COVID-19 pandemic impact on tourism}

The tourism sector, unlike other economic activities with social impact, is based on the interaction between people. Currently, it is one of the sectors the most affected by the COVID-19 pandemic, that influences the economic situation in the market. As a direct consequence, the World Travel and Tourism Council (WTTC) noted that the pandemic crisis in the tourism business was five times more serious than in 2008 . In Ukraine, the pre-quarantine level of inflow was not too high, as there was a huge drop after 2014. If the external borders are closed longer than the quarantine within the country is lifted, there will be an increase in the flow of domestic tourism, which can partially replace the external flow.

In general, the tourism industry occupies a modest place in the economy of Ukraine - about $1.5 \%$ of GDP. Along with outbound tourism, domestic tourism also suffered significant losses. In general, the losses of the tourism industry in Ukraine are estimated at more than 1.5 billion USD. Thus, the tourism sector has suffered global losses due to the introduction of measures to overcome the coronavirus pandemic and the uncertainty of further development of the situation: $96 \%$ of tourist destinations worldwide have been limited (Karaiskaki, Bellos, Papantoniou, 2020). Cruise companies around the world have begun canceling their calls in 2021 due to the coronavirus pandemic. European largest low-cost carrier Ryanair has reduced the number of flights by $20 \%$ since September 2020 due to falling demand. Given the changing nature of the situation, it is necessary to assess the COVID-19 impact on international tourism. Consider in more detail the percentage change in international tourist arrivals based on data of the World Tourism Organization (UNWTO) (Figures 1 and 2).

The international tourist inflows have decreased by $70 \%$ in the first eight months of 2020 compared to the same period the previous year. This came amid the global travel restrictions, including the state borders closure in order to contain the ongoing COVID-19 pandemic.

International arrivals fell by $81 \%$ in July and by $79 \%$ in August 2020, traditionally in the two busiest months of the year and the peak of the summer season in the Northern Hemisphere. However, despite such significant declines, it is worth noting a relative improvement over the decrease of more than $90 \%$ in previous months, as some destinations began to open up to international tourism, mainly in the European Union.

The decrease in the international tourist inflows in January-August 2020 is 700 million less compared to the same period in 2019, which is a loss of 730 billion USD from exports in the international tourism, and exceeds 8 times the loss in 2009 from the impact of the global economic crisis. 


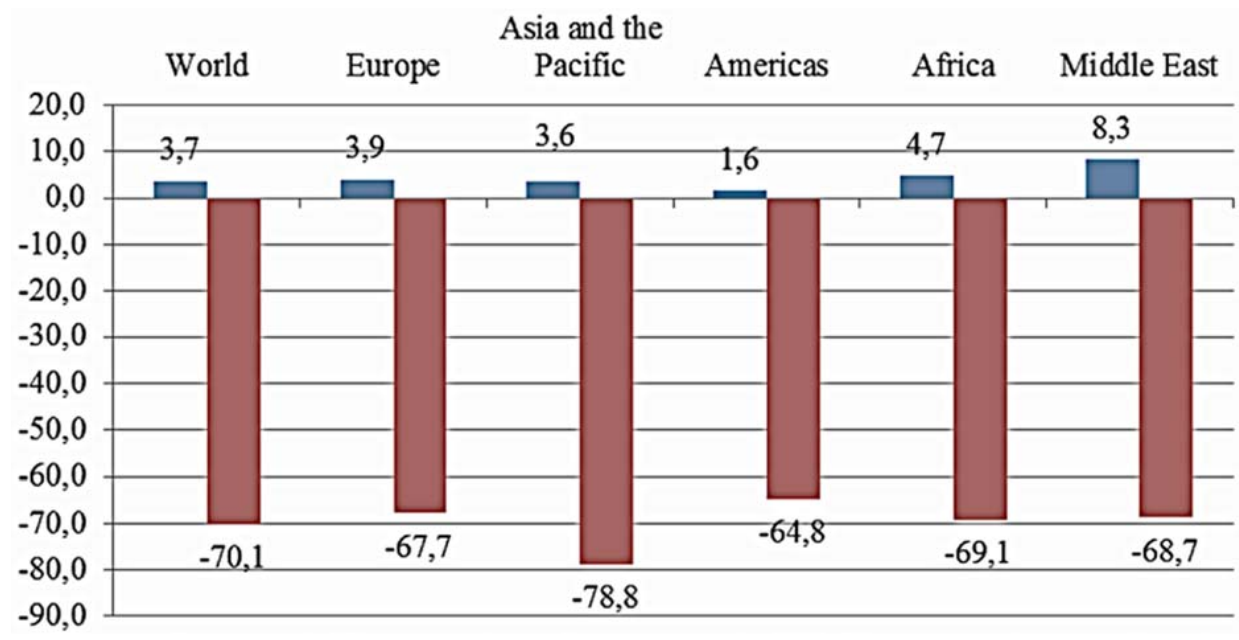

Upper columns - 2019. Lower columns - 2020.

Figure 1. International tourist inflows 2019-2020 by regions in the world (\%)

Source: World Tourism Organization (UNWTO), 2021

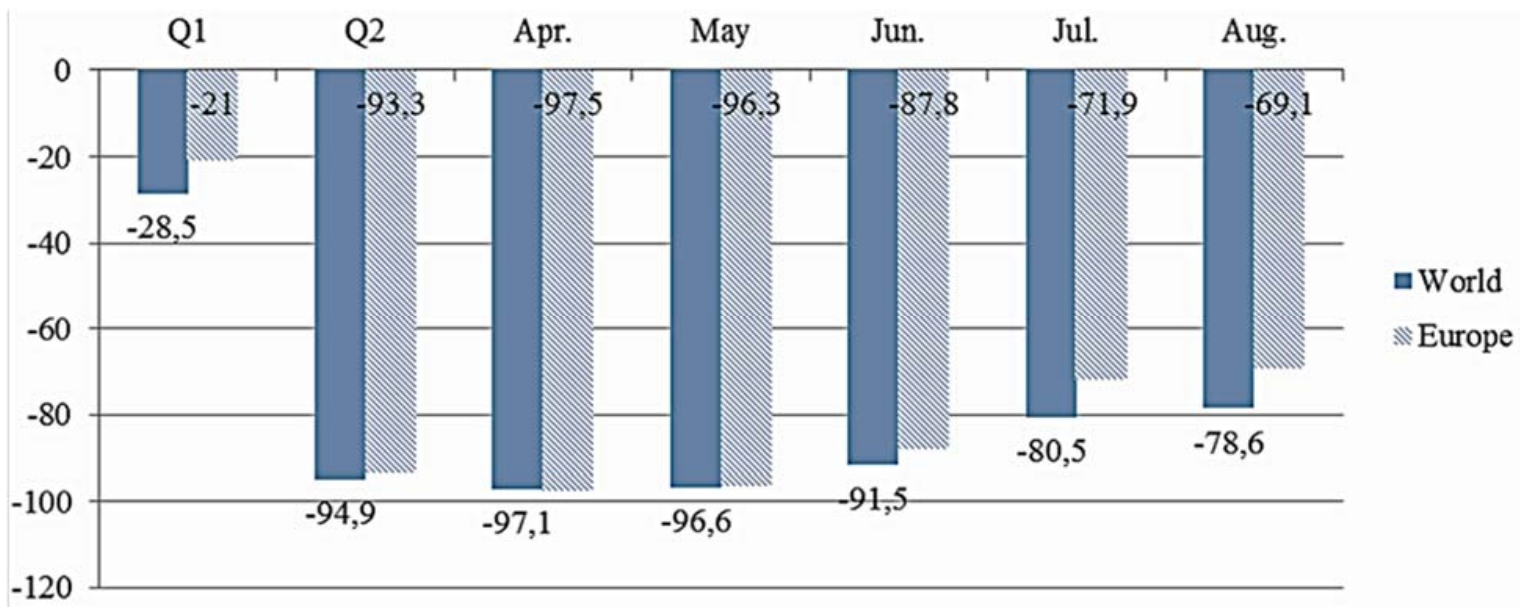

Figure 2. International tourists influxes in the world in 2020 (\%)

Source: World Tourism Organization (UNWTO), 2021

In Asia and the Pacific, the first region to be affected by the pandemic, the number of arrivals decreased by $79 \%$ in January-August 2020. Africa and the Middle East recorded a fall of $69 \%$ in the eight-month period, while Europe has declined by $68 \%$ and the USA - by $65 \%$. The introduction of the travel restrictions has clearly affected international travel (Figure 3) (World Travel \& Tourism Council, 2020).

International tourism spending data continue to reflect very weak demand for outbound trips, although, in several large markets, such as the USA, Germany, and Italy, there has been a slight increase in spending in July and August of this year.

In the European Union regions, it was observed the largest reduction in "full" closure - from $92 \%$ of the total number of arrivals in the region in late April to $8 \%$ in early September). This reflects the significant opening of the destinations in the European Union in late May and June.
In the Asia-Pacific region, this share has been also decreased, although to a lesser extent (from $88 \%$ in April to $64 \%$ in September), as several major destinations, such as China, remain closed. "Complete" closure in the USA has been fallen from $40 \%$ to $25 \%$ over the same period, reflecting the opening of borders at several destinations in the region, mostly in the Caribbean. However, the United States and Canada remained closed.

Unlike other regions, in Africa and the Middle East, the share of "full" closures has been increased in the period between April and June, before declining in July and early September. This is due to the later pandemic impact on these regions compared to Asia and Europe. In Africa, the share of destinations with a "full" stop peaked at $91 \%$ in June and fell to 63\% in September. In the Middle East, the share peaked at $80 \%$ before falling to $49 \%$. 

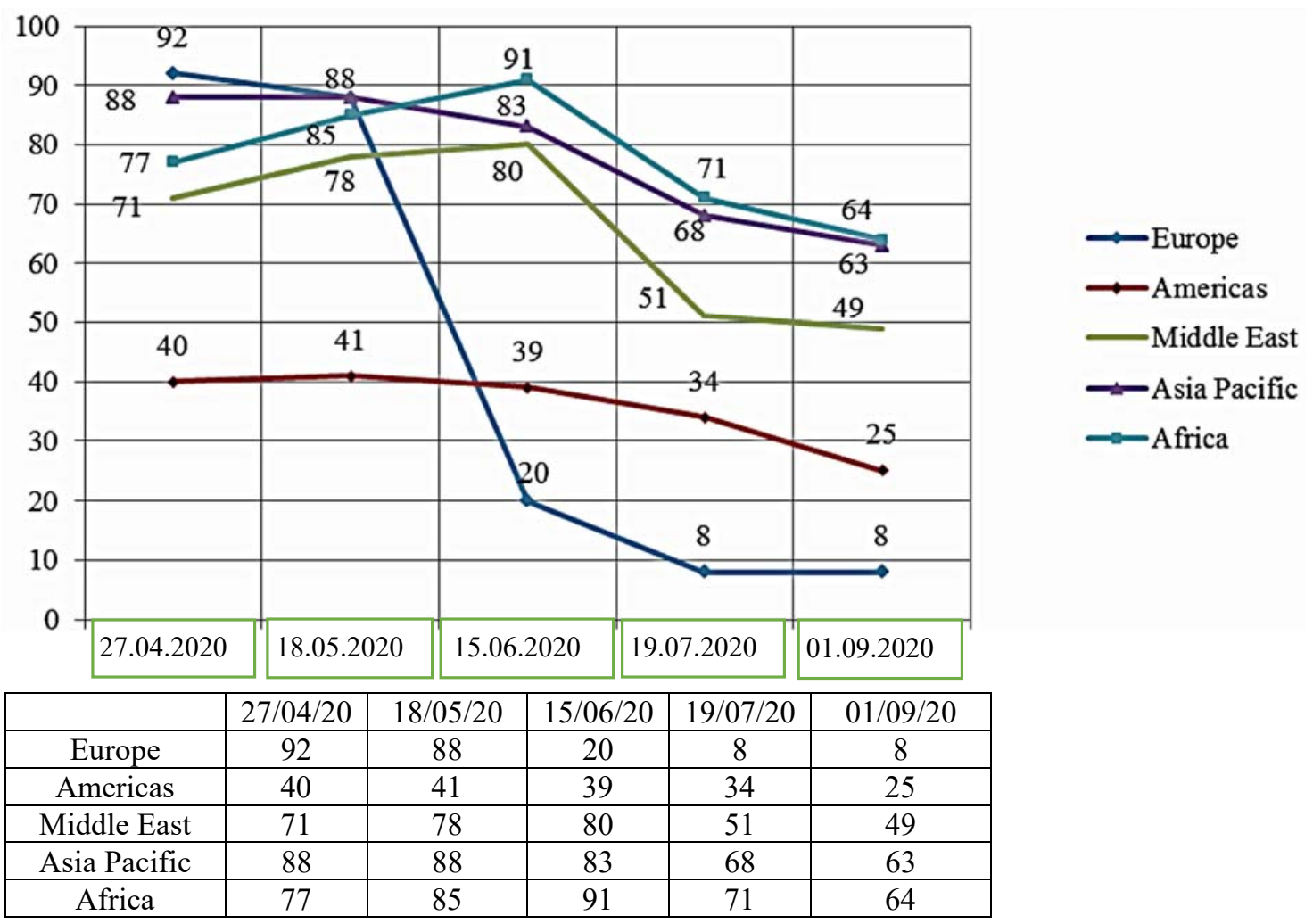

Figure 3. Shares of destinations with full closure of borders by regions, 2020, $\%$ of arrivals in the region*

*share calculated on the basis of international arrivals, as of 2019

Source: World Tourism Organization (UNWTO)

\section{Conclusions}

Thus, the current stage of world economic development is characterized by increasing attention to the development of tourism as the socio-economic transformation catalyst. As a result of the transition from the late ' 80 s of the twentieth century from mass standardized to mass differentiated tourism, the world is observed the formation of new tourist enterprises, increasing the production of tourist products. For many countries, international tourism is an important source of foreign exchange earnings, one of the leading items in the GDP formation. Based on the fact that due to the cumulative effect, the overall contribution of tourism to GDP (especially in the segment of international tourism) is much higher than the direct contribution to GDP (both at the national and international levels), we can conclude that that the tourism sector will continue to be crucial in terms of economic growth in developed and developing countries.

Historically, tourism has demonstrated an active ability to adapt, innovate and recover from shocks. However, the current unprecedented situation requires new approaches, as well as strong multi-level responses and strong partnerships.

Recent trends in Europe show that the opening of borders and tourism is not without risks, as in some regions this has led to an increase in the number of infections, resulting in the introduction of local restrictions by governments.

Now the measures are taken in order to eliminate the direct socio-economic consequences of COVID-19 for tourism and to accelerate the recovery process with the aim of preserving the livelihoods of millions of people, but at the same time, this crisis enables the sector to transform and become more viable, inclusive and stable.

Such a transformation implies that priority in the process of tourism development must be given to the well-being of people, to the strong partnership established with governments, the private sector, citizens, and the international community aiming the better planning and regulation of tourism, and to the creation of the measurement systems in order to assess the impact of this sector on the economy, society, and the environment, and for the proper management of strategic and practical activities.

According to experts, the main trends in the tourism sector during the coronavirus crisis will be (Communication from the commission COVID-19: EU Guidance, 2021):

- development and predominance of domestic tourism, close trips;

- choice of shorter terms of rest, booking closer to the date of departure; 
- increasing the demand for the independent (family) trips by own vehicles and with individual accommodation;

- choice of health, sea and rural tourism (outdoor recreation, accommodation in recreational areas, suburban recreation complexes, rent of green estates, individual houses in compliance with the requirements of social distance and providing the necessary means of protection);

- sanitary and hygienic conditions and the possibility of distancing during living and recreation will be important competitive factors. Taking into account the expected preferences of tourists and the risk of using illegal resorts with the possibility of infection, the support of the tourism industry development has to be provided at the central and local levels. This would reduce the negative effects of the COVID-19 pandemic and create the basis for increasing domestic tourism competitiveness.

The practical realization of demand in the tourist infrastructure will depend on the ability to establish its activities in the conditions of anti-epidemic restrictions. In order to start the tourism recovering, it needs to be revived by the service improving and strengthening the information campaign, in particular by:

- ensuring the availability and reliability of the information on possible travel restrictions and cancellation probability in terms of the main countries of outbound tourism, depending on the degree of epidemic threat;
- creation of mechanisms to guarantee the loss of tourists from the cancellation of the trip due to the spread of the epidemic by providing vouchers for canceled reservations;

- introduction of a transparent mechanism of the targeted use of funds from the tourist tax exclusively for the development of domestic tourism, related infrastructure, and environmental improvement.

- conducting the information and advertising campaigns aimed at reorienting consumer demand for domestic tourism.

There are positive tendencies in world tourism even in the economic crisis conditions. New powerful tourist markets and successful players are appearing now. The WTO analytical forecast of the world tourism development identifies the most popular types of tourism until 2020: adventure, cruise, environmental, cultural and cognitive, thematic, extreme. In world practice, tourism has a significant impact on the development of socio-economic processes in the country and is an important element of its overall strategy. So, the economic and social forecast of the tourism industry is a part of the forecast of the economic and social development of the country. It needs to take into account its features in modern conditions. In the future, the main directions of tourism development will be determined by factors of social, economic, political, and environmental nature. This deepens the processes of uncertainty and the risk factors existence.

\section{References:}

Communication from the commission to the European parliament, the council, the European economic and social committee, and the committee of the regions. Tourism and transport in 2020 and beyond. European Commission. 2020. Available at: https://ec.europa.eu/info/sites/info/files/communication-commission-tourism-trans-port2020-and-beyond_en.pdf (accessed June 21, 2021).

Communication from the commission COVID-19. Towards a phased and coordinated approach for restoring freedom of movement and lifting internal border controls. European Commission. 2020. Available at: https://ec.europa.eu/info/sites/info/files/communication_freemove-ment.pdf (accessed June 21, 2021).

Communication from the commission COVID-19. Guidelines on the progressive restoration of transport services and connectivity. European Commission. 2020. Available at: https://ec.europa.eu/info/sites/info/files/ communication_transportservices.pdf (accessed June 21, 2021).

Commission recommendation of 13.5 .2020 on vouchers offered to passengers and travellers as an alternative to reimbursement for cancelled package travel and transport services in the context of the COVID-19 pandemic. European Commission. 2020. Available at: https://ec.europa.eu/info/sites/info/files/recommendation vouchers_en.pdf (accessed June 21, 2021).

Communication from the commission COVID-19: EU Guidance for the progressive resumption of tourism services and for health protocols in hospitality establishments. European Commission. 2020. Available at: https://ec.europa.eu/info/sites/info/files/communication_tourismservices_healthprotocols.pdf (accessed June 21, 2021).

Global Europe 2050. Luxembourg, Publications Office of the European Union, 2012. Available at: https://op.europa.eu/en/publication-detail/-/publication/32cfa157-57fc-409db7c0-75b50faafale (accessed June 21, 2021).

Karaiskaki, T., Bellos, I., and Papantoniou, S. Plan to cautiously reboot tourism sector. Available at: https: / / www.ekathimerini.com/252521/article/ekathimerini/news/plan-tocautiously-reboot-tourism-sector (accessed June 21, 2021).

Mazaraki,A.A.(2019).Determinants of tourism development.ZbirkamaterialivMizhnarodnoinaukovopraktychnoi konferentsii [Collection of materials of the International scientific-practical conference], Turyzm XXI stolittia: hlobalni vyklyky ta tsyvilizatsiini tsinnosti [Tourism of the XXI century: global challenges and values of civilization]. Kyiv: KNTEU. 
OECD Tourism Trends and Policies (2020). Available at: https://www.oecd.org/cfe/tourism/oecd-tourismtrends-and-policies-20767773.htm (accessed June 21, 2021).

Tourism and transport: Commission's guidance on how to safely resume travel and reboot Europe's tourism in 2020 and beyond. An official website of the European Union. Available at: https://ec.europa.eu/commission/ presscorner/detail/en/ip_20_854 (accessed June 21, 2021).

World Travel \& Tourism Council (2020). Available at: http://www.wttc.org (accessed June 21, 2021).

World Tourism Organization (UNWTO) reports (2020). Available at: https://www.unwto.org/internationaltourism-and-covid-19 (accessed June 21, 2021). 